\title{
The absolute chronology of East Chia Sabz: a Pre-Pottery Neolithic site in Western Iran
}

\author{
Hojjat Darabi', Reza Naseri', Ruth Young² and Hassan Fazeli Nashli' \\ 1 Department of Archaeology, University of Tehran, IR \\ hdarabi@ut.ac.ir; r.nasery@gmail.com; hfazelin@ut.ac.ir \\ 2 School of Archaeology and Ancient History, University of Leicester, UK \\ rly3@leicester.ac.uk
}

\begin{abstract}
East Chia Sabz is a PPN site located in the Seimareh Valley, western Iran. ${ }^{14}$ C dating results indicated that the site was occupied from the early 9 th millennium to the early $7^{\text {th }}$ millennium BC. As we have very little information about early Neolithic sites in Iran in comparison with the other regions of the Near and Middle East, the site of East Chia Sabz will provide a new benchmark for investigating the Neolithisation process in Iran. It is important to note that further investigation of Chia Sabz will certainly provide more secure information about how and when the Epipaleolithic transition to the Neolithic started in the region. This paper will present the recent excavations at the site, and then, based on the ${ }^{14} \mathrm{C}$ dates, will discuss the site's importance in western Iran.
\end{abstract}

IZVLEČEK - Vzhodni Chia Sabz je najdišče, ki je locirano v dolini Seimareh v zahodnem Iranu in datira $v$ obdobje predkeramičnega neolitika. Rezultati radiokarbonskih datacij so pokazali, da je bilo najdišče poseljeno od začetka 9. do začetka 7. tisočletja pr.n.št. Glede na to, da imamo le malo podatkov o zgodnjeneolitskih najdiščih $v$ Iranu v primerjavi z drugimi regijami na Bližnjem in Srednjem vzhodu, bo najdišče Vzhodni Chia Sabz postavilo nova merila za preiskovanje procesa neolitizacije v Iranu. Opozarjamo, da bodo nadaljnje preiskave najdišča Chia Sabz ponudile bolj zanesljive podatke o tem, kako in kdaj se je začel prehod iz epipaleolitika v neolitik $v$ tej regiji. V članku predstavljamo nedavna izkopavanja na najdišču in razpravljamo o pomenu najdišča v zahodnem Iranu na podlagi radiokarbonskih datumov.

KEY WORDS - neolithisation; Pre-Pottery Neolithic; East Chia Sabz; Western Iran; absolute chronology

\section{Introduction}

The Pre-Pottery Neolithic site of East Chia Sabz or Chia Sabz-e Shraghi (in Persian) is situated in the Seimareh District of western Iran, on the bank of the Seimareh River, with an area of about $100 \times 50 \mathrm{~m}$ at an elevation of $362 \mathrm{~m}$ above sea level (Fig. 1). The Seimareh River is fed by various tributaries, including the two major rivers of Gamas $\mathrm{Ab}$ and Qara $\mathrm{Su}$ in Kermanshah. The river flows towards the southeast, marking the border between the two provinces of Ilam and Lurestan.

The site is located $30 \mathrm{~m}$ above the present river bed and has been cut by two gullies into western and eastern parts. It is important to note that the site was buried by later massive alleviation (Fig. 2). East Chia Sabz was discovered during an archaeological survey in the summer of 2007 (Brojeni 2007) in advance of the Seimareh Dam project. As the site is actually located within the proposed Seimareh Dam reservoir, it is expected to be submerged in the near future. As the main focus of this paper is the absolute chronology of the site, we will largely avoid a detailed description of the data, but before discussing the chronology, it is necessary to look briefly at the excavation itself and also various key data. 


\section{Excavation}

Due to the time limitations on this salvage excavation, an archaeological team from the University of Tehran worked during the spring of 2009 on the site and opened two stratigraphic step trenches and two horizontal trenches (Fig. 3). Our primary aim was to understand the chronology of the site, and also to record the architectural remains, small finds and all other relevant data such as animal or plant remains. All of these were recorded both from the horizontal and vertical excavations during the first season.

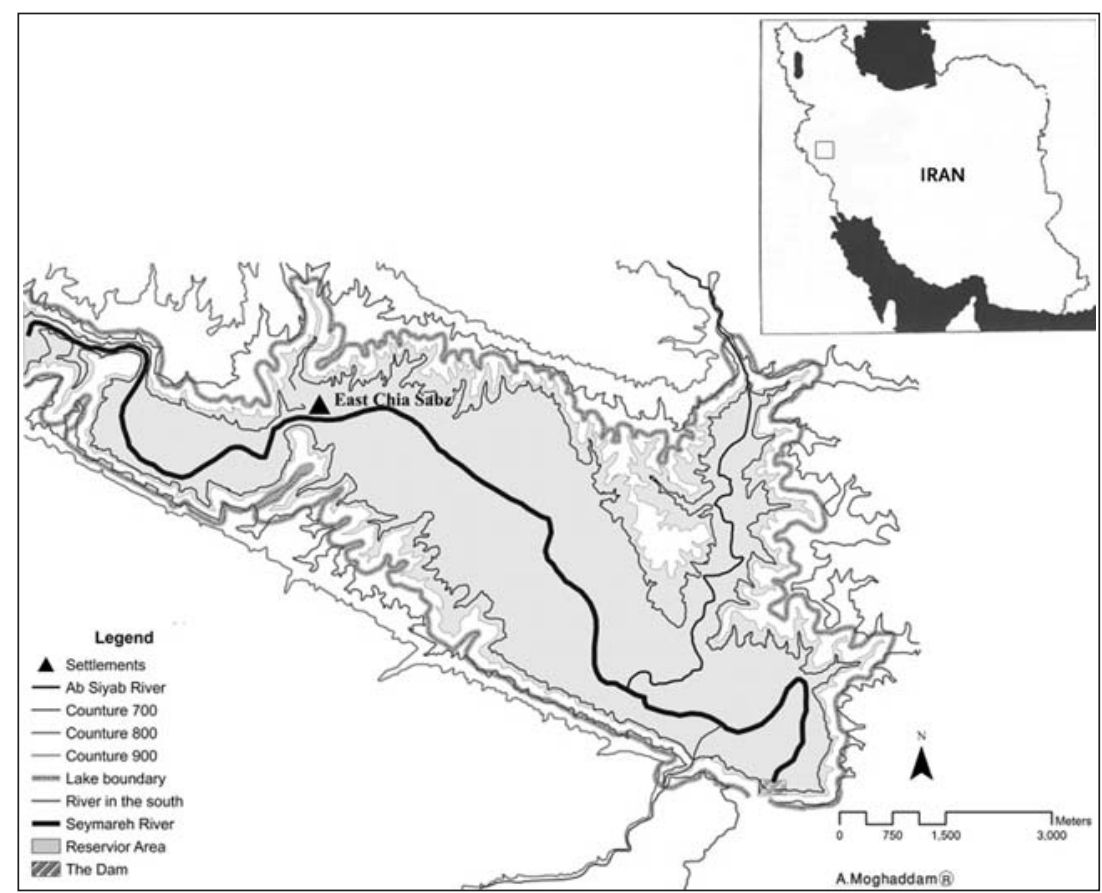

Trench I. A step trench, 2x $2 \mathrm{~m}$ in width, was opened on

Fig. 1. Map showing the location of the site on the Seimareh river bank (modified map originally drawn by A. Moghadam).

the eastern slope of the site. After removing nearly $2 \mathrm{~m}$ of natural deposit, we continued our excavation down to $4.5 \mathrm{~m}$, and then stopped the work before reaching virgin soil, mainly because of the difficulty in distinguishing between the different layers of the trench. Within the trench, all layers had the same grey colour with sporadic cobbles, which seems to have been the result of post-depositional changes such as slope washing. The only architectural remains which were uncovered in the trench consisted of a stone structure with a paved floor (Fig. 4). We also found numerous chipped stones, bone artefacts, stone artefacts, ground stone, ornaments, and animal bones.

Trench II. Another step trench was opened on the southwestern slope of the site, $2 \mathrm{~m}$ wide. Indeed, the chronology of the site is largely based on information from this trench, as we were able to distinguish seven architectural strata within $5.2 \mathrm{~m}$ of the cultural deposit.

Trench III. A 5 x $6 \mathrm{~m}$ trench was opened in the western part of the site close to the western gully, in order to expose the stone architecture which was visible on the surface. The excavation revealed two different architectural strata, both consisting of some rectangular stone cubicles. In the upper stratum, some rooms contained small benches along the walls. No pise or mud brick walls were found. The dimensions of the structures usually did not exceed approximately $1.5 \times 1.5 \mathrm{~m}$ (Fig. 5). Numerous stone vessels, ground stone, chipped stone, bone artefacts, ornaments, and animal bones were recovered from this trench.

Trench IV. A $10 \times 10 \mathrm{~m}$ trench was opened on the southern slope of the site adjacent to the trench II (Fig. 6). In the upper layers, we discovered a stone structure with a paved floor. However, the time limitations meant that we could not uncover any distinct

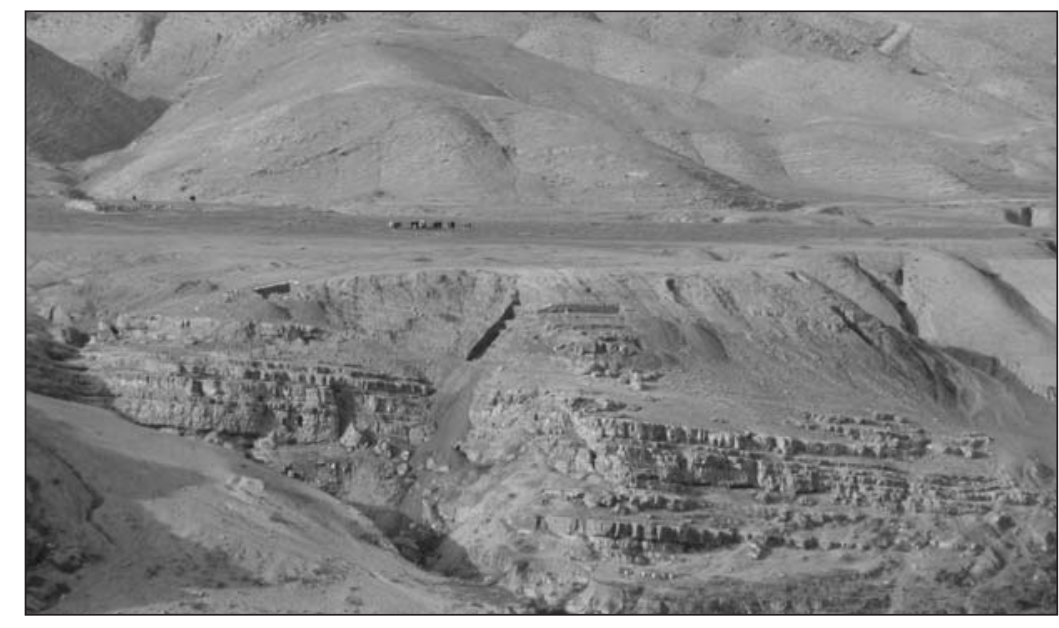

Fig. 2. General view of the site (from the south-west). 


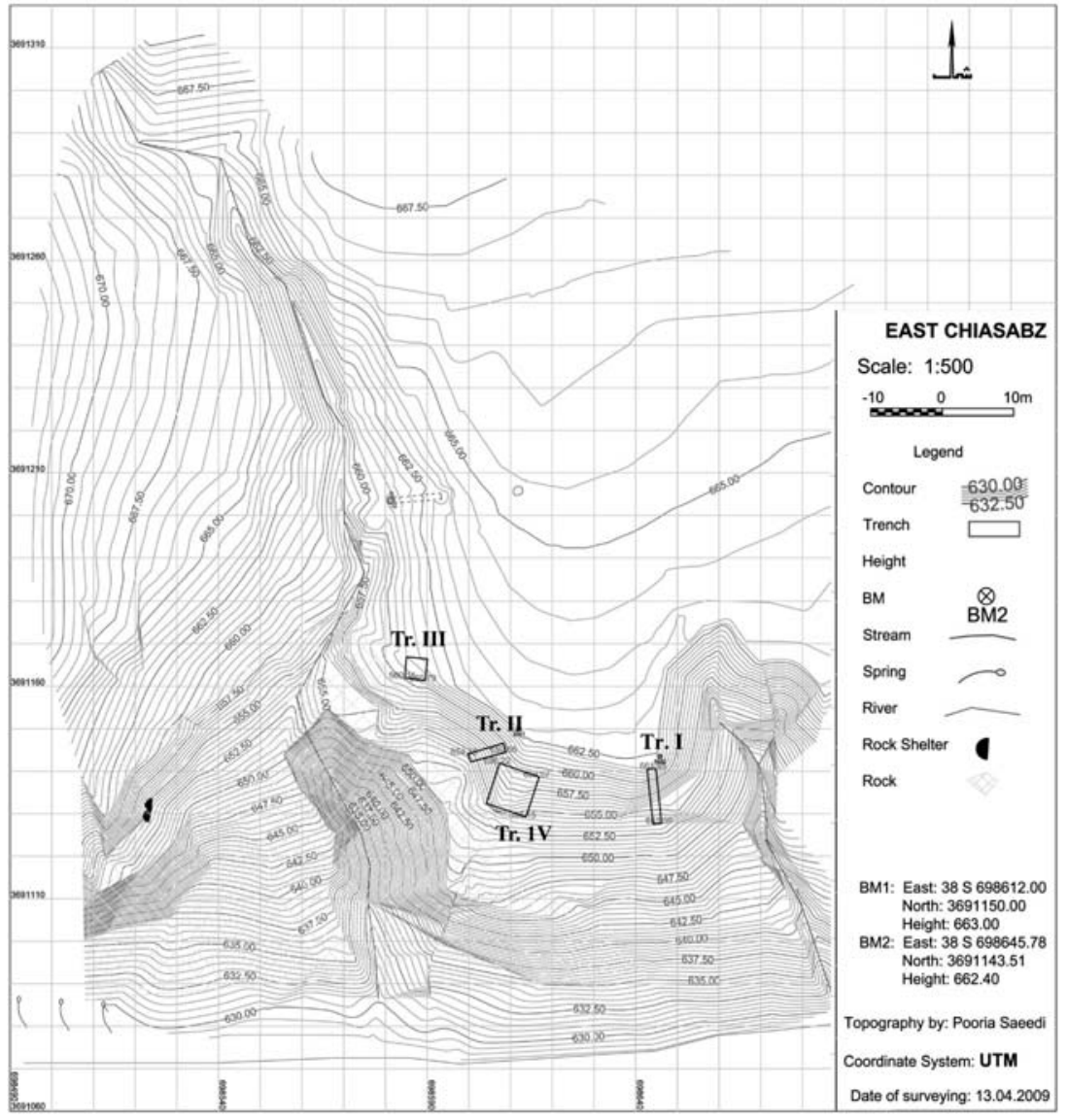

Fig. 3. Site contour map showing the location of trenches.

the chipped stone tools included blades, bladelets, scrapers, borers and awls (Fig. 8). Sometimes a sickle blade can be seen. Denticulate, retouched and notched blades and bladelets, as well side and double scrapers were the most numerous tools. No projectile points have yet been identified from this excavation. The debitage has been divided into flake and nonflake (or debris). Flake is distinguished by having both ventral and dorsal sides and also a striking platform.

The raw materials which were mainly used to make stone tools included a mostly red chert, greyish black flint, and dark black obsidian. The most popular was a kind of chert pebble which could be acquired from the nearby riverbed, but we have no information yet about the other raw mate-

architectural plan, but what we did uncover showed that when people occupied the site for the first time, they appeared to have built a platform on the bedrock. Ground stone, ornaments, chipped stone, bone artefacts, and animal bones were found from this trench.

\section{The finds}

Apart from architectural remains, the other materials recovered during the excavation consisted of chipped stone, ground stone, stone vessels, bone objects, ornaments, stone objects, and animal and human remains. In the following sections, we will present an overview of these different materials, their analyses and our main interpretations.

\section{Chipped stone}

The chipped stone found at the excavation can be divided into three categories: core, tool and debitage. The core category consisted of various blade and flake cores. The blade and bladelet cores were mostly bullet-shaped, although tongue-shaped cores were also significant. Amorphous and multidirectional cores were common among the flake cores (Fig. 7). Thus far, our preliminary study has indicated that rials. While flint might be acquired from the region, obsidian can be taken as an indicator of probable inter-regional contact, as the nearest known source of obsidian is near Lake Urmia in north western Iran. Obsidian was used only in the latest phases of the site's occupation. The preliminary analysis shows that the entire reduction process occurred on site.

\section{Grinding stones}

Stone mortars, bedrock mortars, pebble mortars, querns, pounders and pestles of limestone and sandstone were recovered from the site. The mortars usually had a deep funnel-shaped cavity and sometimes with two cavities on them. Querns had a nearly flat surface which was made by pecking and grinding. Very close to the western area of the site, some $\mathrm{U}$ - and V-shaped bedrock mortars were found, their interior surfaces roughly chiseled. Pebble mortars made from a pebble tended to be convex. Pestles and pounders have signs of use on one or both sides.

\section{Stone vessels}

A total of 42 stone vessel fragments were recovered from the site, mostly from the horizontal trenches, and our first analysis suggests they were mainly di- 
stributed in and around the houses. The most popular forms are bowls with flat bases and semi-globular vessels (Fig. 9). Some vessels have fine walls. Sometimes the vessel has been polished. They are mostly made of limestone, but both sandstone and dolomite were also used. We should also note a single stone vessel fragment found in trench III which was made of marble.

\section{Bone objects}

Awls and several unknown objects were made of bone. In addition to the bone objects considered here, some bone ornaments were found, which we consider within the 'ornaments' section below. Bone awls were recovered from all trenches and were very common. It seems that they were made by breaking a goat/ sheep metapodial and then sharpening one end with some abrasive object (Fig. 10).

\section{Ornaments}

Ornaments include a bracelet fragment (no. 4), a necklace, a bead (no. 6), and a plaque, and so on which usually have a drilled shaft. They were made of both bone and stone (Fig. 11).

\section{Miscellaneous finds}

Six samples of broken shell and three grooved pebbles were classified as miscellaneous finds.

\section{Animal remains}

In total, 11420 bones and bone fragments were recovered, and of these, 584 or $5 \%$ could be identified to element and species. This very low percentage of identified bone can be attributed mainly to pre- and post-depositional factors. The extent of this damage is such that in the whole assemblage there were no complete limb bones - no complete metapodial, tibia, femur, ulna, radius, or humerus was recovered. Indeed, the number of single teeth recorded in the assemblage is also very low. This rather unusual body part representation and fragmentation pattern has interesting implications for butchery activities at

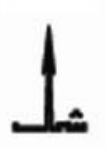

657.87

First Stair

\section{0}
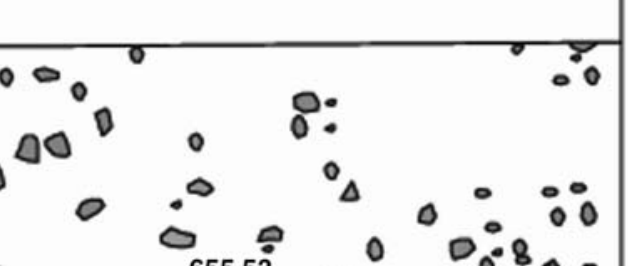

655.53
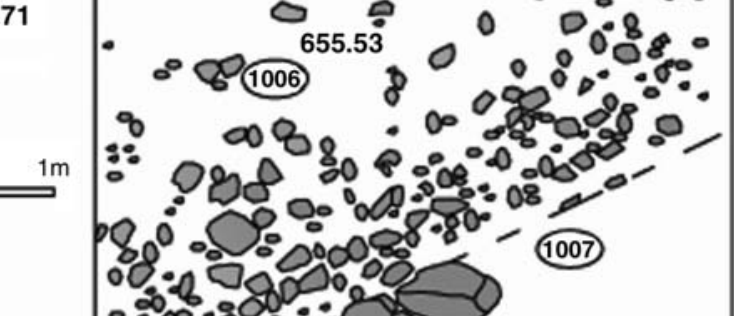

655.71
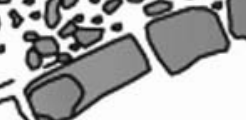

1008

655.53

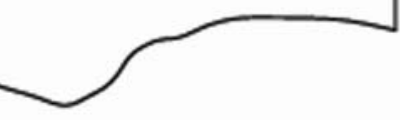

Fig. 4. Architectural remains from Trench I.

the site and the selection of body parts, and will be explored further in future analyses. When we consider the amount of bone in each trench that showed signs of burning, the greatest proportion of burnt bone was recovered from Trench 1 (38\%), then Trench 4 (35\%), Trench $2(17 \%)$, and the lowest proportion from Trench 3 (11\%).

\begin{tabular}{lccccc}
\hline Species & Trench & Trench & Trench & Trench & Total \\
\hline Antelope & $\mathbf{1}$ & $\mathbf{2}$ & $\mathbf{3}$ & $\mathbf{4}$ & \\
\hline Bird & 10 & 5 & 0 & 0 & 15 \\
\hline Cattle & 0 & 4 & 1 & 2 & 7 \\
\hline Canid & 0 & 2 & 0 & 0 & 2 \\
\hline Felidae & 1 & 1 & 1 & 0 & 3 \\
\hline Fish & 2 & 6 & 1 & 2 & 11 \\
\hline Gazelle & 0 & 11 & 0 & 0 & 11 \\
\hline Pig & 3 & 9 & 2 & 2 & 16 \\
\hline Rodent & 0 & 9 & 0 & 0 & 9 \\
\hline Tortoise & 0 & 5 & 0 & 0 & 5 \\
\hline Caprine & 15 & 117 & 33 & 81 & 246 \\
\hline Goat & 13 & 53 & 4 & 7 & 77 \\
\hline Sheep & 38 & 100 & 18 & 18 & 174 \\
\hline Total & 84 & 323 & 62 & 115 & 584 \\
\hline
\end{tabular}

Tab. 1. Different identified animal species. 


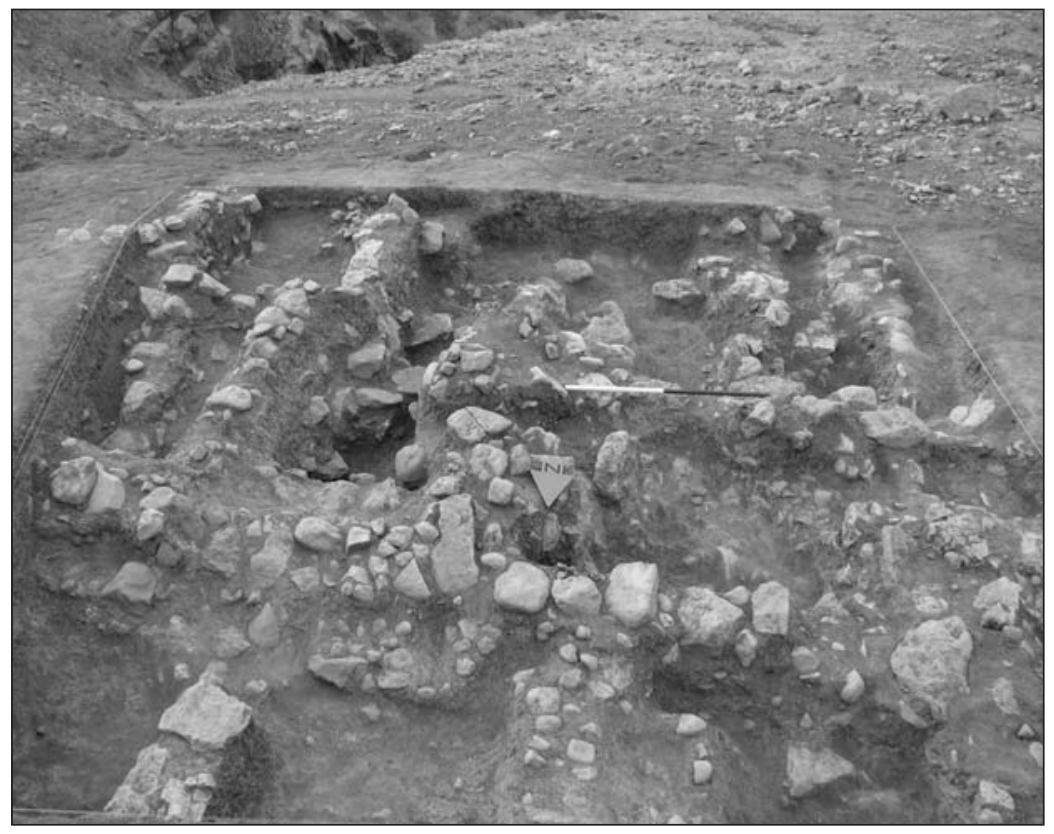

Fig. 5. Architectural remains from Trench III.

Table 1 shows the numbers of each species identified for each trench, and also gives the overall numbers of each species for Chia Sabz. Note that 'caprine' refers to goat and sheep where it has not been possible to distinguish between the two species.

Distinguishing between wild and domesticated species with regard to the sheep, goat and pig is rather problematic, due to the absence of any complete limb bones with good morphology or potential for measurements. In future analyses, we will be using second phalanges in order to compare with published measurements in order to try to determine whether this assemblage comprises wild, domesticated, or mixed animals; however, it should be noted that the assemblage size is very small and this will certainly limit the analyses that can be carried out. Distinguishing between wild and domesticates is clearly a priority, given the interpretation of this site as Pre-Pottery Neolithic on the basis of artefactual evidence, and the expectation that the radiocarbon dates are likely to place the site early in the Neolithic sequence of Iran.

While the absence of any mandible or maxilla with teeth prevents us from using tooth wear estimates to calculate age at death estimates, a considerable number of the fragmented limb articular ends, fragmented metapodials, phalanges and vertebrae were unfused, thus providing an alternative source of information about age at death in this assemblage. In total, 129 unfused articulations or unfused limb fragments were recorded, out of a total of 584 identified bones, indicating that $22 \%$ of this assemblage was less than fully mature at the time of death. Standard fusion rates and age estimates will be used to refine this analysis and allow us to consider the significance of this apparently high slaughter of young animals.

Of the 584 bones and bone fragments that have been identified to species and element, $20 \%$ show some degree of burning. Of the 129 unfused bones and bone fragments that have been identified, $24 \%$ show some degree of burning. As younger, unfused bones may generally be considered less robust than older bones; this may well have implications for the selection and processing of young animals that we will be considering further.

\section{Human remains}

During the excavation, two burials were uncovered in Trench II, one in the first stratum and the other in the sixth stratum. The first had been completely burnt and was in a very bad state of preservation. It should be noted that this burial was adjacent to a fireplace. The second burial, although damaged, was in a much better state of preservation. In this

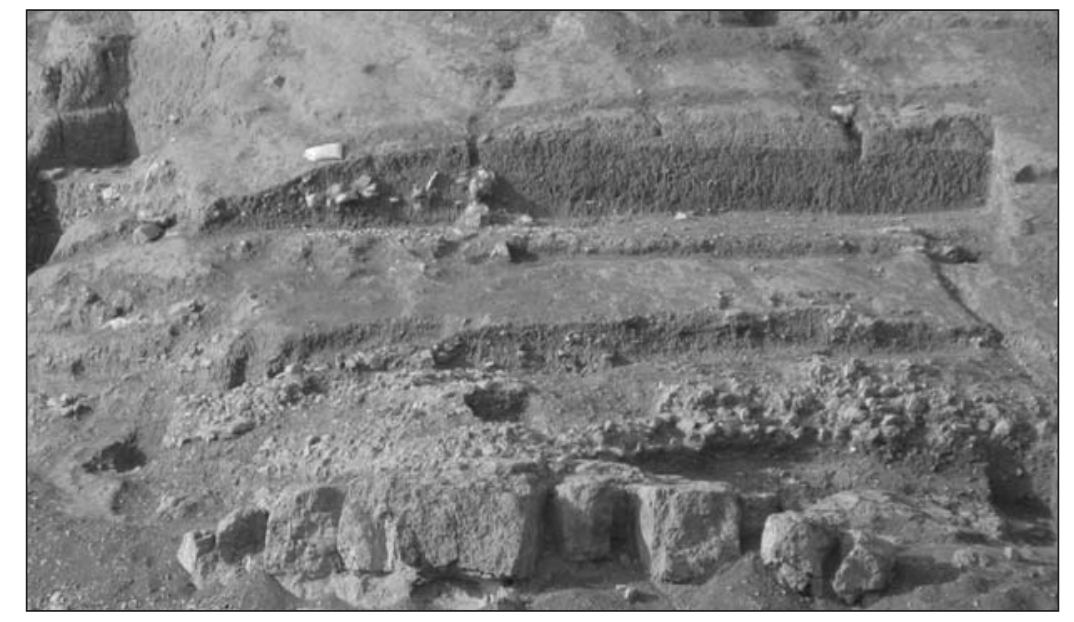

Fig. 6. The location of Trench IV with architectural remains on the bedrock. 
burial, the body was buried in a flexed position, laid on its right side and oriented northwest-southeast. The body was buried within a deposition of mostly pebble stones or a stone platform (Fig. 12). Burial goods included a necklace of perforated land snail shells and a stone bead. Unfortunately, the age and sex of the burials were not determined.

\section{Chronology of the site}

A total of 21 samples were taken from the excavation to characterise the absolute $\mathrm{da}$ ting of the site. Of these, only three samples derived from trench III, the others being from trench II. To date the

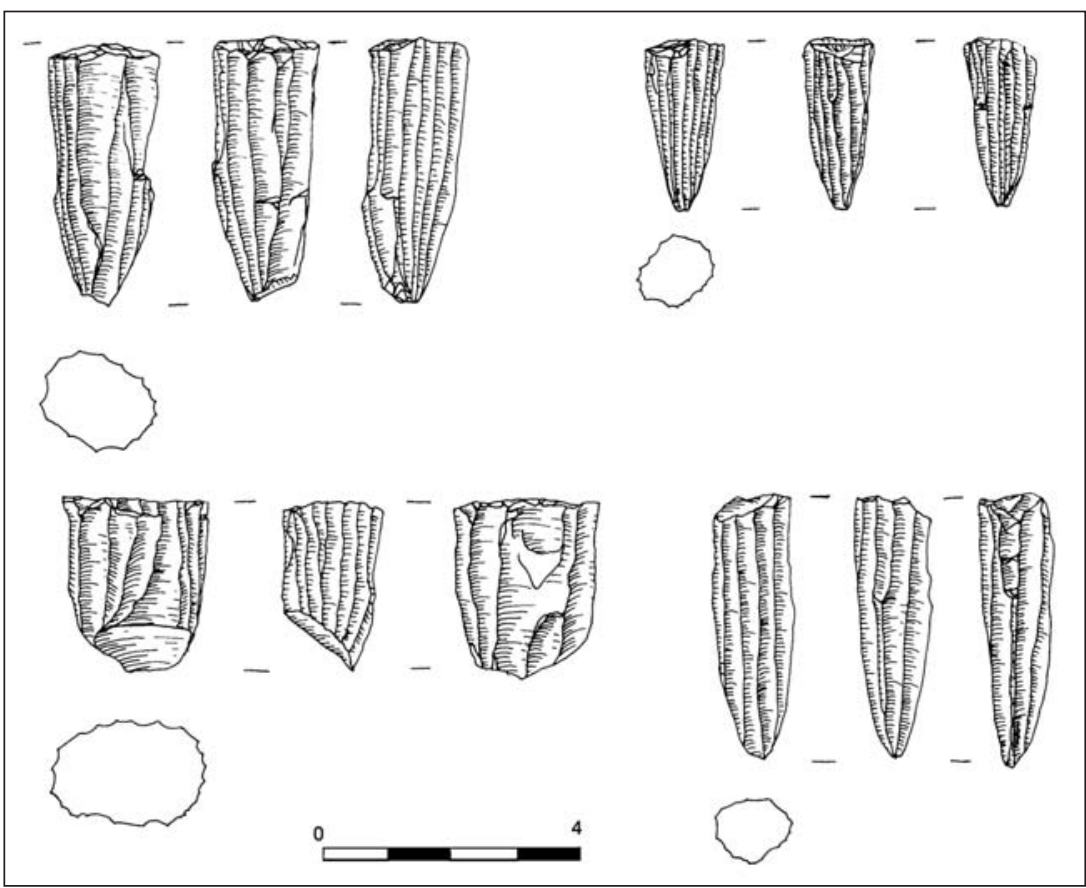

Fig. 7. Various cores. site, we used charcoal samples, of which 11 samples unfortunately failed. Due to its temporal sequence, the radiocarbon dates came only from trench II, as the main stratigraphic trench, and are presented in Table 2.

Based on the dating results, the earliest acquired calibrated date from context $2046(380 \mathrm{~cm}$ below the topsoil or $140 \mathrm{~cm}$ above virgin soil) shows a time range from 8556 to $8311 \mathrm{BC}$. As mentioned, this date does not cover the lower, most cultural deposit that was exactly over the bedrock or virgin soil. Because of the predominant ashy layer in this context, there was no suitable ${ }^{14} \mathrm{C}$ sample and thus it failed. Therefore, we have $140 \mathrm{~cm}$ deposit in depth for the lower layers with no absolute dating. Also, the latest date which indicates the first half of the $8^{\text {th }}$ millennium (7955-7611) BC comes from the context $2026(199 \mathrm{~cm}$ below topsoil in the trench). As a result, there are about two metres of cultural deposit in the upper layers which could not be dated. It should be noted that the trench contained $5.2 \mathrm{~m}$ of stratified deposits vertically. The ${ }^{14} \mathrm{C}$ dating results show a time span of nearly one thousand years from c. 8556 to $c .7611 \mathrm{BC}$, attributable to some $2.0 \mathrm{~m}$ of cultural deposit out of the total depth of $5.2 \mathrm{~m}$ deposit. If it is considered reasonable to estimate an average deposit accumulation rate of $20 \mathrm{~cm}$ per century, then we could extrapolate our dated sequence here to indicate the upper $2.0 \mathrm{~m}$ of cultural deposit in

\begin{tabular}{|lccccccc|}
\hline Lab. No. & Tr. & $\begin{array}{c}\text { Context/ } \\
\text { Depth }\end{array}$ & $\begin{array}{c}\text { Context } \\
\text { type }\end{array}$ & R.N. & $\begin{array}{c}\text { Uncalibrated } \\
\text { Date (BP) }\end{array}$ & $\begin{array}{c}\text { Calibrated } \\
\text { Date (BC) }\end{array}$ & $\begin{array}{c}\text { Probability } \\
\text { (95.4\%) }\end{array}$ \\
\hline OxA-20994 & II & $\begin{array}{c}2026 \\
199 \mathrm{~cm}\end{array}$ & structure & 2095 & $8750 \pm 45$ & $7955-7611$ & $95.4 \%$ \\
\hline OxA-21028 & II & 2028 & deposite & 2108 & $8830 \pm 45$ & $8206-8035$ & $33.0 \%$ \\
& & $194 \mathrm{~cm}$ & & & & $8016-7752$ & $62.4 \%$ \\
\hline OxA-21029 & II & 2037 & deposite & 2117 & $8830 \pm 45$ & $8206-8035$ & $33.0 \%$ \\
& & $217 \mathrm{~cm}$ & & & & $8016-7752$ & $62.4 \%$ \\
\hline OxA-21030 & II & 2042 & structure & 2144 & $9015 \pm 39$ & $8299-8202$ & $93.2 \%$ \\
& & $295 \mathrm{~cm}$ & & & & $8100-8097$ & $0.2 \%$ \\
& & & & & & $8037-8014$ & $2.1 \%$ \\
\hline OxA-21031 & II & 2044 & burial & 2151 & $9180 \pm 40$ & $8485-8293$ & $90.4 \%$ \\
& & $342 \mathrm{~cm}$ & & & & $8537-8511$ & $5.0 \%$ \\
\hline OxA-21032 & II & 2046 & deposite & 2158 & $9225 \pm 40$ & $8556-8311$ & $95.4 \%$ \\
& & $380 \mathrm{~cm}$ & & & & & \\
\hline
\end{tabular}

Tab. 2. ${ }^{14} \mathrm{C}$ dating results from earliest (bottom) to the latest date (top) of Trench II. 


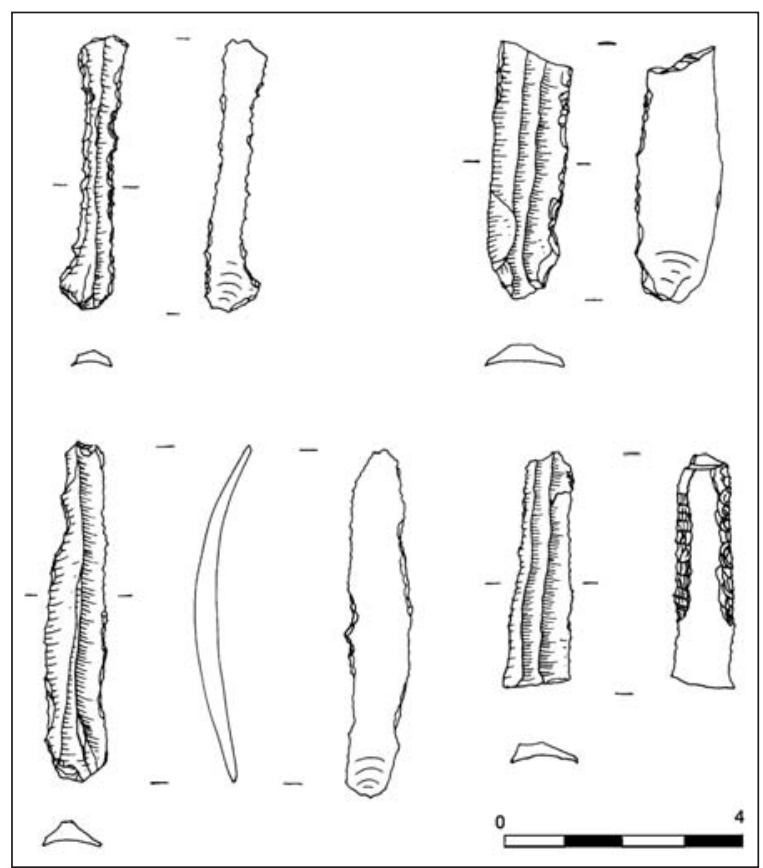

Fig. 8. Chipped stone tools.

depth with no date, which could extend the latest date some one thousand later than the latest acquired ${ }^{14} \mathrm{C}$ date. Although, the $1.4 \mathrm{~m}$ of the lowermost deposit could extend the time span of the sequence by around 700 years earlier than the earliest ${ }^{14} \mathrm{C}$ date estimate, it seems that the determined dates might be expanded temporally to an estimate of occupation between 8800 to $6800 \mathrm{BC}$. Note that this preliminary suggested chronology needs to be seen as the broadest estimated time span during which the site could have been occupied.

\section{Stratigraphy}

As previously mentioned, two step trenches were targeted for chronological purposes; Trench I was not successful in terms of our project aims; thus Trench II was opened. In Trench II, we excavated $5.2 \mathrm{~m}$ of cultural deposits from the topsoil to the virgin soil or bedrock and recorded 51 contexts, 21 layers and seven architectural strata (Fig. 13). Stratification is based on the architectural remains, and ${ }^{14} \mathrm{C}$ dating where available has been used to clarify the chronology.

Stratum I. The first (latest) stratum is characterised by two stone walls with an adjacent paved floor, approximately $2 \times 1 \mathrm{~m}$ and $35 \mathrm{~cm}$ below the topsoil (contexts 2002, 2003 and 2004). Each wall was built by three stones in order; one in east- west and other in south-north direction. In the northeast corner of the trench a density of small pebbles $c .1-5 \mathrm{~cm}$ in diameter were found, which could be a pavement.
Stratum II. This stratum (context 2020 and 2022) is marked by two rows of stone wall which were built on a stone platform. The second stratum was uncovered at $70 \mathrm{~cm}$ and continued down to $120 \mathrm{~cm}$ below the topsoil. It seems that, firstly, a platform (context no. 2020) was built as high as $40-50 \mathrm{~cm}$ and then the wall was laid on top of this platform. Here, we again found two rows of converging stone, with a high density of variant sized pebbles and irregular stones inside them.

Stratum III. The third stratum (contexts 2024, 2025,2026 and 2027) is indicated by a row of two boulders which was built on a stone platform such as that found in phase 2 , at $188 \mathrm{~cm}$ below the topsoil. The platform was built out of various sized pebbles as high as $44 \mathrm{~cm}$. Based on the ${ }^{14} \mathrm{C}$ dating, this stratum could be dated to the first half of the $8^{\text {th }}$ millennium BC.

Stratum IV. Although the fourth stratum (context no. 2035) is not seen on the section sketch, it is characterised by a row of stones at $220 \mathrm{~cm}$ below the topsoil. This stone wall was oriented in a southwestnortheast direction, approximately $170 \times 50 \mathrm{~cm}$ in size. As it is adjacent to the dated context of 2037 (which belongs to some time around $8000 \mathrm{BC}$ or somewhat later), it seems reasonable to suggest both contexts are contemporary.

Stratum V. The fifth stratum (context no. 2040) is composed of a stone platform as high as $35 \mathrm{~cm}$ and an overlaid ground mortar. This mortar indicates
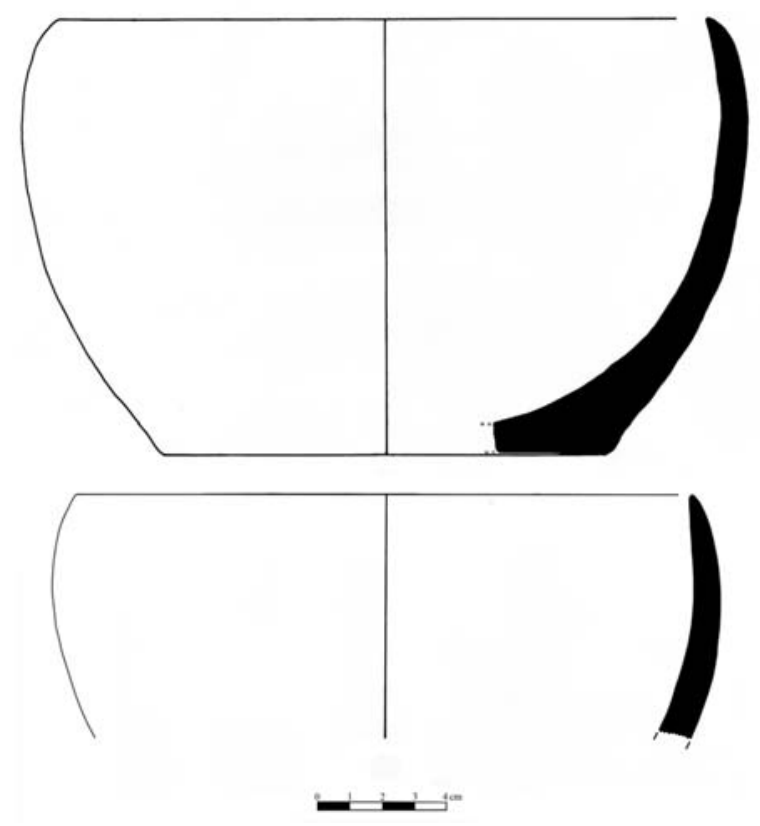

Fig. 9. Stone vessels. 
that the platform could also be used as a paved floor. This stratum uncovered at $250 \mathrm{~cm}$ in depth and could be dated to some time between late $9^{\text {th }}$ and early $8^{\text {th }}$ millennium BC.

Stratum VI. The sixth stratum (context 2043 and 2045) consists of a platform which is built by medium-sized pebble and boulders as high as $35-40 \mathrm{~cm}$, located $245 \mathrm{~cm}$ below the topsoil of the trench. The excavation resulted in the discovery within the platform of a human burial which dated to the second half of the $9^{\text {th }}$ millennium $\mathrm{BC}$.

Stratum VII. Context 2046 down to the bedrock is designated as the seventh stratum and is indicated by $140 \mathrm{~cm}$ of ashy deposit with some sporadic small stones at $380 \mathrm{~cm}$ below the topsoil. Indeed, no solid architectural re-

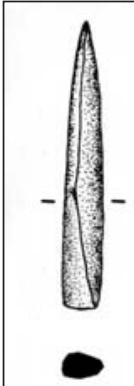

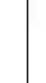

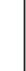

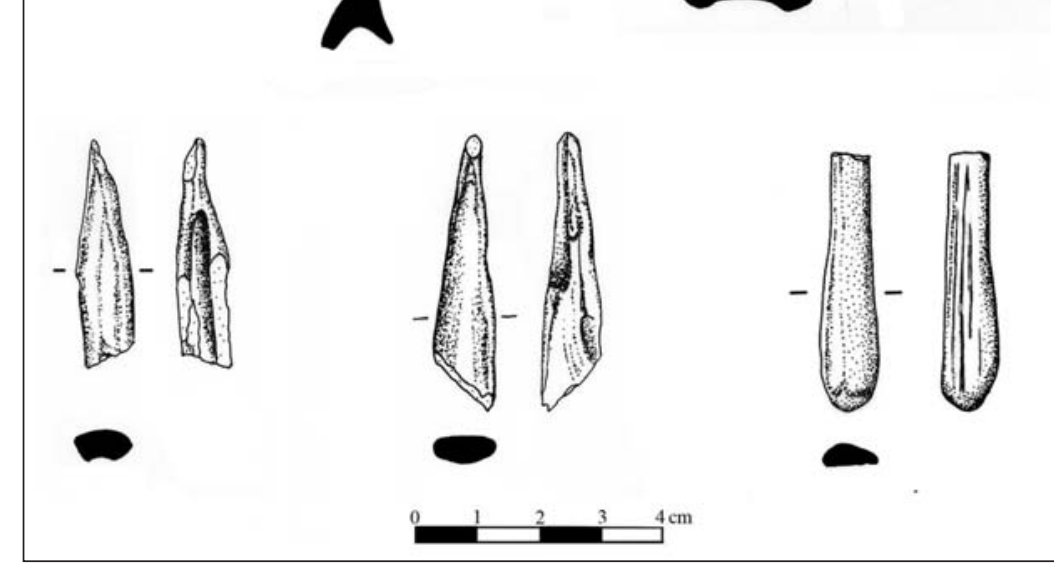

Fig. 10. Bone awls. mains were found and the ${ }^{14} \mathrm{C}$ samples from this stratum unfortunately failed. However, we attribute this lowest stratum to the early $9^{\text {th }}$ millennium BC. It should be noted that stratigraphy has thus far been based on the architecture and the definition of cultural phases will be carried out when the final analysis of all the various data is complete.

\section{Concluding remarks}

The excavated material and also ${ }^{14} \mathrm{C}$ dating show that East Chia Sabz can provide a new roadmap for
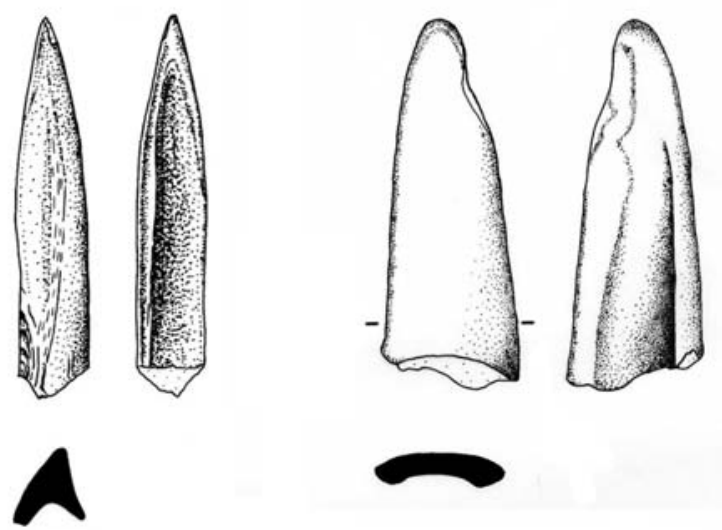

future discussions on the Neolithisation process in western Iran. While the architectural remains differentiate it from other early Neolithic sites in the region, the other materials such as the chipped stone industry and stone vessels generally place East Chia Sabz within the Pre-Pottery cultures of western Iran. Since this paper is more focused on the absolute chronology of the site rather than giving a full preliminary report of the excavation, we now move to a short discussion of the dating results and their importance in the Neolithic archaeology of Iran (see Tab. 3).

\begin{tabular}{|l|l|c|c|c|}
\hline \multirow{2}{*}{\begin{tabular}{l}
\multirow{2}{*}{ Site name } \\
Sarab
\end{tabular}} & \multirow{2}{*}{ Location } & Absolute & Relative & \multirow{2}{*}{ Reference } \\
\cline { 3 - 4 } Chogha Sefid & Kermanshah & $6200-5500$ & - & McDonald 1979 \\
\hline Fasil & Deh Luran Plain & $6700-5500$ & - & Hole 1977 \\
\hline Guran & near Mehran plain & - & $6500-6000$ ? & Darabi Q Fazeli 2009 \\
\hline Abdul Hosein & Hulailan & $6500-5500$ & & Mortensen 1975 \\
\hline Ali Kosh & Nor Abad & $7000-6000$ & $7200-6500$ & Pullar 1990 \\
\hline Choga Khulaman/Golan & Deh Luran plain & $7500-5500$ & $7000-6000$ & Hole et al. 1969 \\
\hline Asiab & Mehran plain & - & $9000-7000$ ? & Darabi Q Fazeli 2009 \\
\hline Ganj Dareh & Kermanshah & $8700-8500 ?$ & $8000-7000$ & How 1983; Zeder 2008 \\
\hline East Chia Sabz & Harsin,Kermanshah & $8450-6800$ & $8000-7000$ & Smith 1990 \\
\hline Sheikhi Abad & Seimareh & $8500-7500$ & $8800-6800$ & current article \\
\hline
\end{tabular}

Tab. 3. Chronological chart showing the date of Neolithic sites in Western Iran. 
Before the 1980s, some Neolithic sites in western Iran, notably Asiab and Sarab, were excavated during the Iranian Prehistoric Project by R. Braidwood near Kermanshah (Braidwood et al. 1961). Other important excavated Neolithic sites in the Central Zagros such as Ganj Dareh (Smith 1976) and Guran (Mortensen 1975) have also been dated, although not yet fully published.

The archaeological projects from the late 1970s onward have not been continued in western Iran and the focus of fieldwork shifted to western parts of the Fertile Crescent. This resulted in changing some hypotheses. For example, Hole suggested that the Neolithic occurred in Iran two thousand years later than elsewhere in the wider region (Hole 1999. 20-22) He also hypothesised that the earliest Neolithic sites in Iran such as Ganj Dareh were the result of an eastward movement. If the Iranian Neolithic is the result of eastward migration or diffusion, then we would ask why no similar archaeological material has been recovered from the early Neolithic sites of both regions? Note that the previous researches indicated a long gap between late Epipaleolithic and Early Neolithic

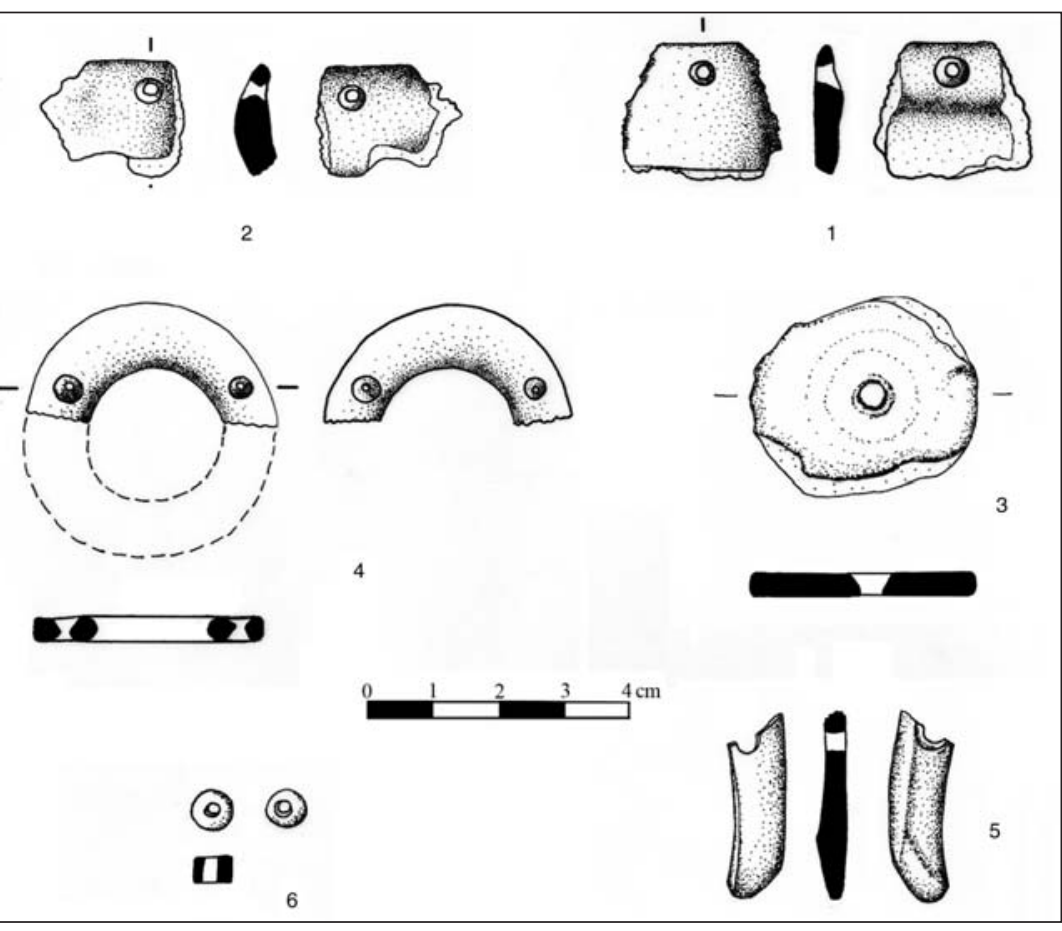

Fig. 11. Ornaments (no. 4 and 6 made of stone, the rest of bone).

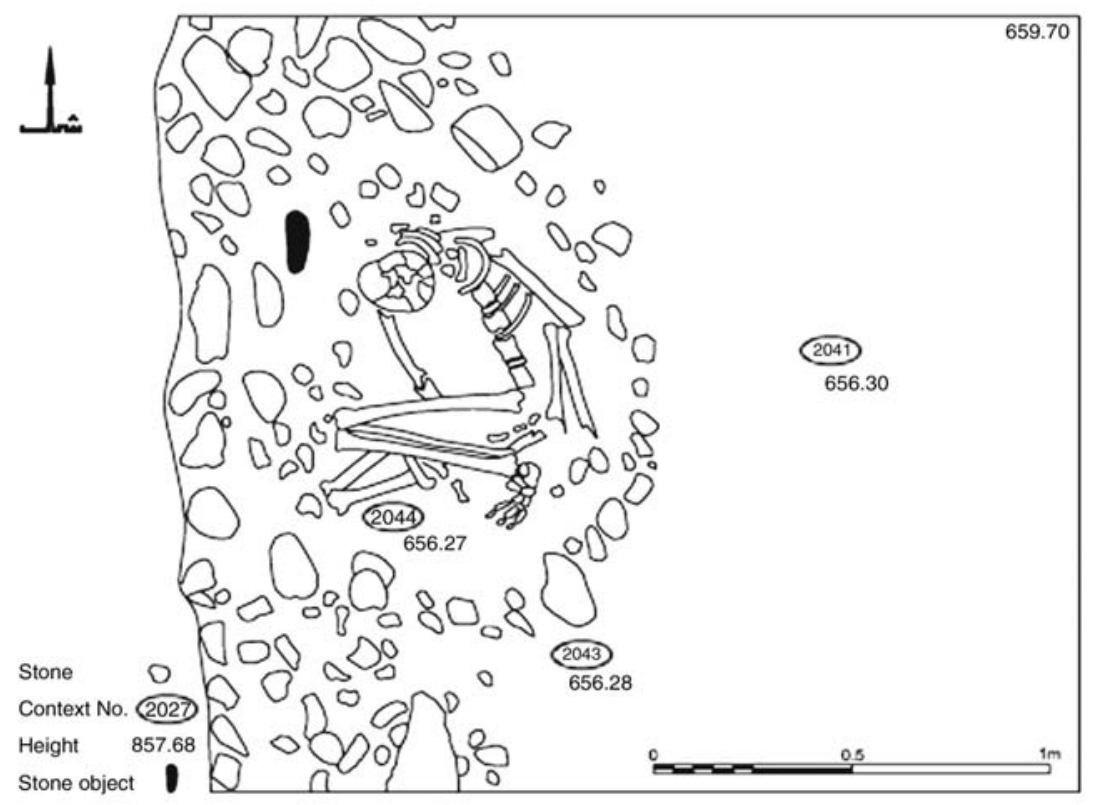

Fig. 12. Burial in Trench II. in western Iran. On the one hand, the Epipaleolithic sites such as Warwasi rock shelter, Ghar-i-Khar, Mar Ruz, and Mar Gurgalan Sarab belong to the recent stage of the Zarzian industry (Mortensen 1993.168). It is worth noting that, based on its relative chronology, the Warwasi site may have continued until sometime around $10000 \mathrm{BC}$ (Olszewski 1993. 214). On the other hand, according to absolute dating, the earliest Neolithic sites including Ganj Dareh (Smith 1990), Asiab (Howe 1983) and Ali Kosh (Hole et al. 1969 ) belong to the $9^{\text {th }}$ and $8^{\text {th }}$ millennia BC. It also worth mentioning that radiocarbon dating was in its infancy when the early Neolithic sites were excavated and there was considerable confusion over the chronological placement of Zagros sites across this transitional period (Zeder 2008.240). Therefore, it seems that new dating can shed some light on the early Neolithic of Iran. Of interest, is the newly excavated PrePottery Neolithic site of Sheikhi Abad in Kermanshah, indicating an early $10^{\text {th }}$ millennium BC settlement (Matthews et al. 2010). Also, a reconsideration of the faunal assemblage from Asiab showed 


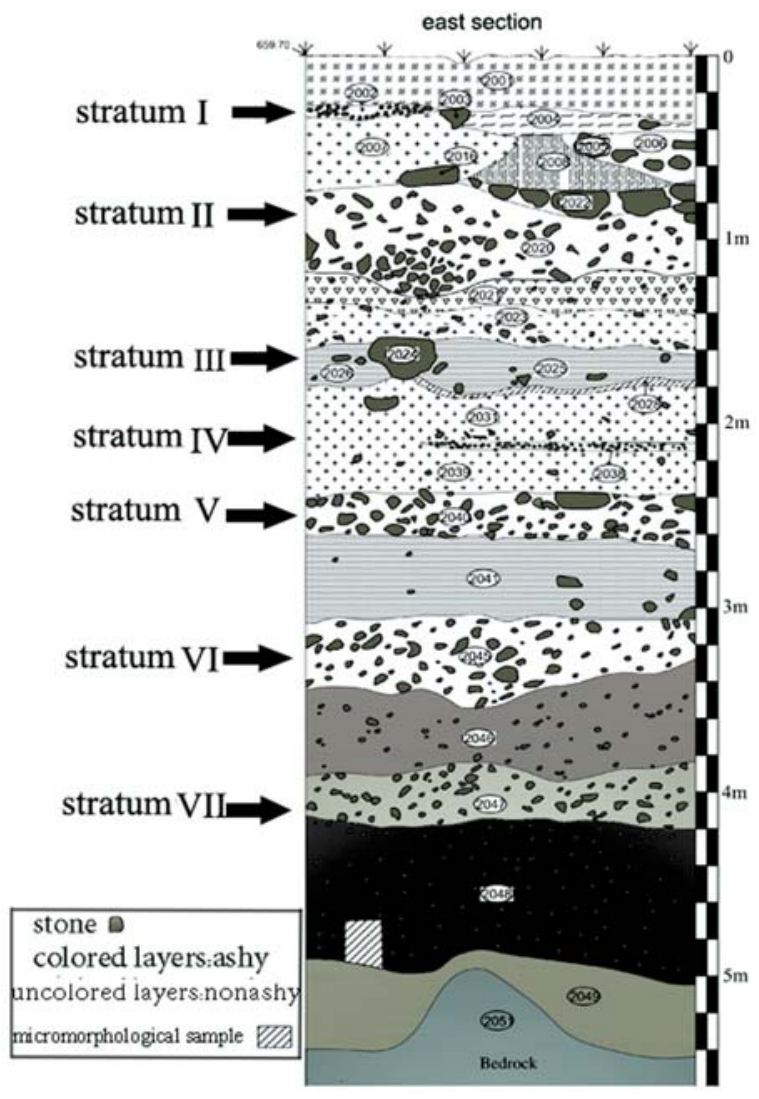

Fig. 13. Architectural strata in trench II. that it was a campsite with no evidence of domestication, dating to the first half of the $9^{\text {th }}$ millennium BC (Zeder 2008). Absolute dates show that the site of East Chia Sabz belongs at least to the first half of the $9^{\text {th }}$ millennium $\mathrm{BC}$ and, considering that the lowermost deposits are exactly over the virgin soil with no absolute dating, we can even imagine an earlier date for the earliest occupation of the site. Thus it seems that the site can be very useful for understanding more about the cultural gap between the late Epipaleolithic and Early Neolithic and even assign the Neolithic of the region to an earlier date than already indicated by the previous researches. In the nearby Hulailan Valley a long settlement gap was observed by Mortensen, stretching from the Epipaleolithic period to the mid 7 th millennium $\mathrm{BC}$, when Tepe Guran was occupied (Mortensen 1975. 5). Thus it can be suggested that East Chia Sabz can bridge the gap between the Epipaleolithic settlements to the earliest site of the Hulailan Valley in this region. These absolute dates also show that the beginning of the Neolithic in Iran was not later than in other regions of the Near East as Hole had asserted, and the discovery and exploration of new sites in this region will bring crucial new data to bear on this debate.

\section{$\therefore$}

\section{REFERENCES}

BRAIDWOOD R. J. 1961. The Iranian Prehistoric Project 1959-1960. Iranica Antiqua 1: 3-7.

BROJENI S. R. 2007. Archaeological survey in the Seimareh Dam drainage. ICAR. Tehran: (Unpublished report, in Persian).

DARABI H., FAZELI H. 2009. The Neolithic of the Mehran Plain: an Introduction. Antiquity 83(322). Project Gallery. Online http://antiquity.ac.uk/projgall/darabi322/.

HOLE F., FLANNARY K. and NEELY J. 1969. Prehistory and human ecology of the Deh Luran Plain. Michigan. Ann Arbor.

HOLE F. 1999. Revisiting the Neolithic. In A. Alizadeh, Y. Majidzadeh and S. Malek Shahmirzadi (eds.), The Iranian world: essays on Iranian art and archaeology. Iran University Press, Tehran: 13-27.

HOWE B. 1983. Karim Shahir. In L. S. Braidwood, R. J. Braidwood, B. How, C. A. Reed and P. J. Watson (eds.), Prehistoric Archaeology along the Zagros flanks. The
Oriental institute of the University of Chicago, Chicago: 23-154.

MATTHEWS R., MOHAMMADIFAR Y., MATTHEWS W. and MOTARJEM A. 2010. Investigating the early Neolithic of Western Iran: the Central Zagros Archaeological Project (CZAP), Antiquity 84(323). Project Gallery. Online http:// antiquity.ac.uk/projgall/matthews323/

MCDONALD M. M. A. 1979. An Examination of Mid-Holocene Settlement Patterns in the Central Zagros Region of Western Iran. PhD Dissertation, Department of Anthropology, University of Toronto.Toronto.

MORTENSEN P. 1975. Survey and soundings in the Holailan valley 1974. In F. Bagherzadeh (ed.), Proceeding of the $3^{\text {rd }}$ Annual Symposium on Archaeological Research in Iran. Iranian Centre for Archaeological Research, Tehran: 1-12.

1993. Paleolithic and Epipaleolithic Sites in the Hulailan Valley, northern Luristan. In D. I. Olzewski and H. L. Dibble (eds.), The Paleolithic Prehistory of the Za- 
gros- Taurus. The University Museum Monograph 83. University museum Symposium Series V. University of Pennsylvania, Philadelphia: 159-168.

OLZEWSKI D. I. 1993. The Zarzian Occupation at Warwasi Rock shelter, Iran. In D. I. Olzewski and H. L. Dibble (eds.), The Paleolithic Prehistory of the Zagros- Taurus. The University Museum Monograph 83. University Museum Symposium Series V. University of Pennsylvania, Philadelphia: 207-236.

PULLAR J. 1990. Tepe Abdul Hosein: A Neolithic Site in Western Iran, Excavation 1978. BAR International Series 563. Oxford.

SMITH P. E. L. 1976. Reflection on four Seasons of Excavations at Tepe Ganj Dareh. In F. Bagherzadeh (ed.), Pro- ceeding of the $4^{\text {th }}$ Annual Symposium on Archaeological Research in Iran. Iranian Centre for Archaeological Research, Tehran: 11-22.

1990. Architectural Innovation and Experimentation at Ganj Dareh, Iran. World Archaeology 21(3): 323-335.

ZEDER M. A. 2008. Animal Domestication in the Zagros: an Update and Directions for Future Research. In E. Vila, L. Gourichon, A. M. Choyke and H. Buitenhuis (eds.), $A r$ chaeozoology of the Near East VIII. Proceedings of the eighth international Symposium on the Archaeozoology of southwestern Asia and adjacent areas. Tome I. Lyon, June $28^{\text {th-July }} 1^{\text {st }}, 2006$.Travaux de la Maison de L'orient et le la Méditerranée $\mathrm{N}^{\circ}$ 49, Lyon: 243-77. 